\section{Canadian Institute of Forestry Incorporation, Objects \& By-laws \\ Revised 1987}

\section{Index}

Auditors

By-laws

Corporate Seal

Directors Board of

Duments, Signing and Certifying of

Examiners Board of

Executive Committee

Financial Year

Head Office

Meetings and Voting

Membership Classes of

Membership

Officers Agents and Employees

Rules and Regulations

Sections

Voting

Translation

\section{Institut Forestier du Canada Incorporation, Buts et Règlements}

1987 révisé

\title{
Incorporation and Objects
}

Under the provisions of Part II of the Canadian Corporations Act, 1965, under Letters Patent of September 1950, and under Supplementary Letters Patent of December, 1965, the Institute is incorporated as a corporation without share capital and with the name of Canadian Institute of Forestry - Institut Forestier du Canada for the purpose of carrying on in more than one Province of Canada, without pecuniary gain to its members, the following objects

1. To improve all aspects of forestry ${ }^{1}$ in Canada.

2. To foster public understanding of forestry forests and forest industry including their importance to the economy and their role in the maintenance and improvement of environmental quality.

3. To advance members in their knowledge of forestry.

4. To cultivate an esprit de corps among members.

5. To publish a professional and scientific forestry journal.

6. To cooperate with other organizations having similar objectives.

\section{By-laws}

These By-laws are as adopted at the Annual General Meeting of the Institute in October 1975, revised in October 1978, October 1979, October 1980, October 1981, September 1982, 1983, August 1984, September 1985, 1986, August 1987 and subsequently approved by the Corporation Branch, Department of Consumer and Corporate Affairs.

\section{Corporate Seal}

The seal of the Institute shall be in such form as has been prescribed by the Directors of the Institute and shall be endorsed with the words Canadian Institute of Forestry Institut Forestier du Canada.

Forestry: the science, the art and the practice of managing and using for human benefit the natural resources that occur on and in association with forest lands.

\section{Index}

Assemblées 9

Bureau des examinateurs $\quad 12$

Comité exécutif

Conseil d'administration

Engagement des officiers, agents et employés

Exercice financier

Membres, catégories de

Règlements

Règlementation concernant les membres

Règles de pratique

Sceau de la corporation

Sections

Siège social

Signature et attestation des documents

Vérifjcateurs

Votes

Traduction

\section{Incorporation et Buts}

En vertu des dispositions de la deuxième partie de la Loi sur les Corporations canadiennes, 1965, et en vertu des lettres patentes émises en septembre 1950, ainsi que des lettres patentes supplémentaires émises en décembre 1965, I'Institut est incorporé comme corporation sans capital action, sous le nom de Canadian Institute of Forestry - Institut forestier du Canada ayant pour but de réaliser, dans plus qu'une province du Canada et sans but lucratif pour ses membres, les fins suivantes:

1. Améliorer tous les aspects de la foresterie ${ }^{1}$ au Canada

2. Favoriser une meilleure compréhension par le public de la foresterie, des forêts et de l'industrie forestière, et une meilleure appréciation de leur importance économique et de leur rôle dans la préservation et l'amélioration de la qualité de l'environnement.

3. Perfectionner les connaissances forestières de ses membres.

4. Cultiver un esprit de corps dans les rangs de la profession.

5. Publier une revue professionnelle et scientifique sur la foresterie.

6. Collaborer avec les autres organisations dont les objectifs sont similaires.

\section{Règlements}

Les règlements sont tels qu'adoptés par l'assemblée générale annuelle de l'Institut tenue en octobre 1975, révisés en octobre 1978, en octobre 1979, 1980,1981, en septembre 1982, 1983, août 1984, septembre 1985, 1986, août 1987 et subséquemment approuvés par le Bureau des Corporations du ministère fédéral de la Consommation et des Corporations.

\section{Le sceau de la corporation}

Le sceau de l'Institut a la forme qui a été déterminée par les administrateurs de l'Institut; ce sceau porte l'inscription suivante: Canadian Institute of Forestry - Institut forestier du Canada. 


\section{Head Office}

The head office of the Institute shall be located at Suite 1005 , 151 Slater Street, Ottawa, K1P 5H3, in the Province of Ontario, or such other place as the Board of Directors may determine.

\section{Classes of Members}

3.1 Fellows and Honorary Members

3.1.1 Fellow qualification. A member or ex-member who has made outstanding contributions to the advancement of forestry or to the Institute may be elected a Fellow of the Institute by not fewer than two-thirds of the votes cast at a meeting of the Board of Directors.

3.1.2 Fellow privileges. Fellows of the Institute shall be exempt from payment of membership dues and shall enjoy the rights and privileges accorded to Active Members.

3.1.3 Honorary qualification. A non-member who has made outstanding contributions to the advancement of forestry may be elected an Honorary Member by not fewer than two-thirds of the votes cast at a meeting of the Board of Directors.

3.1.4 Honorary Privileges. Honorary Members shall be exempt from payment of membership dues and shall enjoy the rights and privileges accorded to Active Members.

3.2 Active Members.

The following are eligible for Active membership and shall be admitted upon acceptance by a Section Council or the Executive Committee.

\subsubsection{Graduates}

3.2.1.1 Forestry graduates. Persons who have received a graduate or post-graduate degree in forestry, forest engineering or applied science in forestry from a college or university recognized by the Board of Directors as providing courses of satisfactory standing.

3.2.1.2 Allied-science graduates engaged in forestry. Persons who are not eligible under Sub-section 3.2.1.1 but who have received a graduate or post-graduate degree in an allied science from a college or university recognized by the Board of Directors as providing courses of satisfactory standing, and who have been engaged for at least five years in some branch of forestry.

3.2.2 Other Qualifications. The following are eligible for Active membership and shall be admitted upon the recommendations and approvals specifically noted for each class.

3.2.2.1 Affiliate members in responsible forestry positions. Affiliate members holding responsible forestry positions who have been sponsored by two Active members, recommended by a Section Council and approved by the Board of Examiners. 3.2.2.2 Special qualification. Persons in positions of professional responsibility who have special qualifications and long and valuable experience in forest activities and who have been recommended by a Section Council, and approved by the Board of Examiners.

3.3 Affiliate Members.

3.3.1 Technicians or Technologists. The following are eligible for Affiliate membership and shall be admitted upon acceptance by a Section Council or the Executive Committee. 3.3.1.1 Forestry Technicians or Technologists. Persons who have received a diploma or certificate in forestry, forest engineering or applied science in forestry from a Technical School, Community College or "Collége d'Enseignement Général et Professionnel", CEGEP, recognized by the Board of Directors as providing courses of satisfactory standing. 3.3.1.2 Allied-Science Technicians or Technologists engaged in forestry. Persons not eligible under sub-section 3.3.1.1. but who have received a diploma or certificate in an allied science from a Technical School, Community College or "Collége d'Enseignement Général et Professionnel", CEGEP, or other institution recognized by the Board of Directors as having courses of satisfactory standing and to

\section{Siège social}

Le siège social de l'Institut est situé au 151, rue Slater, bureau 1005, Ottawa, K1P 5H3, Province d'Ontario, ou dans toute autre localité choisie par le Conseil d'administration.

\section{Catégories de membres}

\subsection{Membres émérites et membres honoraires}

3.1.1 Qualifications des membres émérites. Tout membre ou ancien membre qui a contribué de façon particulièrement remarquable à l'avancement de la foresterie ou de l'Institut peut être élu membre émérite de l'Institut par un minimum de deux tiers des voix, lors d'une réunion du Conseil d'administration.

3.1.2 Privilèges attachés au titre de membre émérite. Les membres émérites de l'Institut sont exemptés de payer une cotisation et jouissent des mêmes droits et privilèges que les membres actifs

3.1.3 Qualifications des membres honoraires. Toute personne ne faisant pas partie de l'Institut, qui a contribué de façon particulièrement remarquable à l'avancement de la foresterie, peut être élue membre honoraire par un minimum de deux tiers des voix à une réunion du Conseil d'administration.

3.1.4 Privilèges attachés au titre de membre honoraire. Les membres honoraires sont exemptés de la cotisation et jouissent des mêmes droits et privilèges que les membres actifs.

\subsection{Membres actifs}

Les personnes décrites ci après sont admissibles comme membres actifs et sont admises si elles sont acceptées par le Conseil d'une Section ou par le Comité exécutif.

\subsubsection{Personnes diplômées}

3.2.1.1 Bacheliers en foresterie. Toute personne détenant un baccalauréat, une maîtrise ou un doctorat en foresterie, en génie forestier ou en sciences appliquées (foresterie), d'un collège ou d'une université dont le programme d'études est approuvé par le Conseil d'administration.

3.2.1.2 Diplômés en sciences appliquées pratiquant la foresterie. Les personnes qui ne sont pas éligibles en vertu du règlement

3.2.1.1 mais qui détiennent un baccalauréat, une maîtrise ou un doctorat dans une science connexe, d'un collège ou université dont le programme d'études est approuvé par le Conseil d'administration et qui travaillent depuis au moins cinq ans dans une branche de la foresterie.

3.2.2 Autres qualifications. Les personnes décrites ci après sont admissibles comme membres actifs et sont admises sur recommandation et après approbation, tel que noté spécifiquement dans chaque cas.

3.2.2.1 Membres affiliés occupant un poste de commande en foresterie. Les membres affiliés occupant un poste de commande en foresterie dont la demande d'admission comme membres actifs est parrainée par deux membres actifs, recommandée par le Conseil d'une Section et approuvée par le Bureau des examinateurs.

3.2.2.2 Titre d'éligibilité spécial. Les personnes occupant un poste de responsabilité professionnelle qui ont démontré de grandes qualités, qui ont acquis une longue expérience dans les activités forestières et qui ont été recommandées par un Conseil de Section et approuvées par le Bureau des examinateurs.

\subsection{Membres affiliés}

3.3.1 Techniciens et technologistes. Les personnes décrites ci-après sont admissibles à titre de membres affiliés et sont admises après approbation par le Conseil d'une Section ou par le Comité exécutif.

3.3.1.1 Techniciens ou technologistes forestiers. Les personnes qui ont reçu un diplôme ou un certificat en foresterie, en génie forestier ou en sciences appliquées à la foresterie d'une école technique, d'un collège communautaire ou d'un collège d'enseignement général et profession- 
have been engaged for two years in some branch of forestry 3.3.2 Other Qualification. Persons who do not otherwise qualify for affiliate membership but who have been engaged for at least five years in the practice of forestry or forest engineering, or have indicated interest in forestry and who are considered to be in position to contribute to the advancement of forestry principles.

3.4 Student Members.

The following are eligible for Student Membership:

3.4.1 Existing Members in full-time study. Persons who are already members of the Institute and who are registered as students on a full-time basis.

3.4.2 Graduate or undergraduate students in full-time study. Persons who are already qualified for Active or Affiliate Membership and who are registered as full-time students, or persons who are registered as students in a course that would qualify them for Active or Affiliate membership under Subsection 3.2.1.1. or 3.3.1.1., respectively.

3.5 Sustaining Members.

3.5.1 Qualifications for Sustaining Membership. The following are eligible for Sustaining Membership:

3.5.1.1 Existing Institute Members. All Fellow, Honorary, Active, Affiliate and Student Members of the Institute and members having retired status are eligible for Sustaining Membership if they supplement their regular annual dues by a minimum amount as indicated in the current scale of membership dues.

3.5.1.2 Organizations. Sustaining Membership is available for organizations that are involved in or provide a service to Canadian forestry or to the Institute. All applications for Sustaining Membership should include a statement describing the applicant's intentions of providing financial support to the Institute and shall be subject to approval by the Executive Committee. A minimum contribution to the Institute shall be described in the current scale of membership dues.

\section{Membership}

\subsection{Dues}

4.1.1 Amount and conditions of payment. The scale of membership dues and the conditions of payment may be recommended by the Board of Directors and must be ratified by vote at an annual general meeting called for the purpose, inter alia, of considering the matter.

4.1.2 Date due and non-payment.

4.1.2.1 Dues are due and payable on the first day of July each year.

4.1.2.2 If the dues of any Member have not been paid on or before the last day of December of the current year, then such a delinquent member shall be struck-off the rolls and notified accordingly by mail to the last known address.

4.1.3 Reinstatement. Formal application for reinstatement of a member struck-off the rolls for non-payment of dues shall be considered for acceptance if accompanied by payment of dues for the current year plus a reinstatement charge which may be established from time to time by the Executive Committee

\subsection{Resignation}

4.2.1 Any member may withdraw from the Institute by submitting a letter of resignation to the Executive Director. nel, C.E.G.E.P., reconnu par le Conseil d'administration apte à dispenser des cours de qualité satisfaisante.

3.3.1.2 Techniciens ou technologistes en science connexes travaillant en foresterie. Personnes non-eligibles en vertu du règlement 3.3.1.1 mais qui ont reçu un diplôme ou un certificat dans une science connexe d'un école technique, d'un collège communautaire ou d'un collège d'enseignement général et professionnel, (C.E.G.E.P.), ou d'une autre institution reconnue par le Conseil d'administration pour la qualité satisfaisante de ses cours et qui ont travaillé durant deux ans dans une branche quelconque de la foresterie.

3.3.2 Autres qualifications. Personnes qui ne sont pas autrement éligibles comme membres affiliées mais qui ont travaillé durant au moins cinq ans en foresterie ou en génie forestier, ou qui ont montré un intérêt en foresterie et qui sont considérées comme étant en position de contribuer à l'avancement des principes de la foresterie.

3.4 Membres étudiants.

Les personnes suivantes sont admissibles comme membres étudiants:

3.4.1 Membres étudiants réguliers. Personnes qui sont déjà membres de l'Institut et qui sont inscrites comme étudiants réguliers.

3.4.2 Etudiants réguliers du second ou du premier cycle. Personnes qui sont déjà admissibles comme membres actifs ou affiliés et qui sont inscrites comme étudiants réguliers, ou personnes qui sont inscrites comme étudiants à un cours qui les rendrait admissibles comme membres actifs en vertu du règlement 3.2.1.1 ou comme membres affiliés en vertu du règlement 3.3.1.1.

3.5 Membres auxiliaires.

3.5.1 Qualifications des membres auxiliaires. Les personnes suivantes sont admissibles comme membres auxiliaires:

3.5.1.1 Membres en règle de l'Institut. Tous les membres émérites, honoraires, actifs, affiliés et étudiants de l'Institut et les membres retraités sont admissibles comme membres auxiliaires s'ils ajoutent à leur cotisation annuelle le montant minimum indiqué dans le barème des cotisations.

3.5.1.2 Sociétés. Les sociétés qui oeuvrent en foresterie ou qui servent la cause de la foresterie au Canada ou celle de I'Institut peuvent devenir membres auxiliaires. Toute candidature au titre de membre auxiliaire contient un énoncé des intentions du candidat de supporter financièrement l'Institut et doit être approuvée par le Comité exécutif. La contribution financière minimale à l'Institut est indiquée dans le barème des cotisations des membres.

\section{Règlementation concernant les membres}

\subsection{Cotisation annuelle}

4.1.1 Montant et modalités de paiement. Le barème de la cotisation annuelle des membres et les modalités de paiement peuvent être proposés par le Conseil d'administration, mais par la suite doivent être ratifiés lors de l'assemblée générale annuelle ou à l'occasion d'une assemblée générale extraordinaire convoquée pour discuter de ce point en particulier.

4.1.2 Echéance et défaut de paiement.

4.1.2.1 La cotisation annuelle est due et payable chaque année le premier jour de juillet.

4.1.2.2 Si un membre n'a pas versé sa cotisation le ou avant le dernier jour de décembre de la même année, alors ce membre retardataire est rayé du tableau des membres et est avisé en conséquence par courrier envoyé à sa dernière adresse connue.

4.1.3 Réinscription. Une demande officielle de réinscription d'un membre rayé du tableau de l'Institut à cause d'un manquement à verser sa cotisation annuelle n'est considérée que si, à cette demande officielle, le membre joint le paiement de sa cotisation annuelle pour l'année en cours, en plus d'un frais de réinscription établi de temps à autre par le Comité exécutif. 


\subsection{Expulsion}

4.3.1 Any member may be required to withdraw from the Institute by a vote of three-quarters of the members of the Board of Directors.

4.4 Retirement

4.4.1 Application for retired status. An Active or Affiliate Member who has been a member of the Institute for fifteen or more years and who retires from such activity as was the basis of his/her qualification for membership, may apply to his/her Section Council for a continuation in that class of membership without payment of National dues. "Retirement" shall be interpreted as retirement from full-time employment with a substantial reduction in income.

4.4.2 Examination. The Section Council shall examine an application for Retired status and may recommend acceptance by the Executive Committee. Under special circumstances the minimum requirement of fifteen years previous membership may be waived if Council so advises. 4.4.3 Forestry Chronicle for Retired Members. Retired members may receive The Forestry Chronicle at the subscription rate set by the Board of Directors and approved by the membership.

4.5 Applicants without Section Affiliation

4.5.1 Applications for Active, Affiliate, Student and Retired membership from applicants who are not affiliated with a Section should be forwarded to the Executive Director for consideration by the Executive Committee.

\section{Board of Directors}

\subsection{Composition}

5.1.1 The Board of Directors shall consist of one representative from each Section together with the members of the Executive Committee. All Directors must be Active Members of the Institute.

5.2 Appointment of Section Representatives and Alternates 5.2.1 Method of appointment. After the annual general meeting of the Institute, and before the first day of July following, each Section shall elect or appoint its representative who will assume the duties of Director. Election maybe either by letter ballot or at a Section general meeting or, if the Section By-laws permit, by appointment by the Section Council. In like manner each Section shall elect an Alternate who shall act in the place of, and enjoy all the rights and privileges of the Director only in the latter's unavoidable absence or in the circumstances governed by By-law 5.3. Within one month of the election of a Director and an Alternate, the Secretary of the Section concerned shall notify the Executive Director of the result of the election.

5.2.2 Term of office. A Director representing a Section shall assume office on the first day of July following election, and shall hold office until the thirtieth day of June following. A Director may be re-elected for subsequent terms.

5.2.3 Avoidance of duplication. A member may not act as a Section Representative on the Board of Directors and as an elected Officer of the Institute concurrently. An appointment as Section representative (or alternate) on the Board is void when the incumbent assumes office as a member of the Executive Committee. In such an event the Section concerned shall elect or appoint to the Board another representative or other alternate. This election or appointment shall take place at least thirty days before the next ensuing annual general meeting, or according to By-law 5.2.1,
4.2 Démission

4.2.1 Tout membre peut se retirer de I'Institut en faisant parvenir une lettre de démission au directeur exécutif.

4.3 Expulsion

4.3.1 Tout membre peut être expulsé de l'Institut à la suite d'un vote des trois quarts des membres du Conseil d'administration.

4.4 Retraite.

4.4.1 Demande pour se prévaloir du statut de retraité. Un membre actif ou affilié qui a fait partie de l'Institut pendant quinze ans ou plus et qui prend sa retraite d'un travail qui le rendait éligible à cette catégorie de membre de l'Institut peut faire une demande au Conseil de sa Section pour que soit continuée dans cette catégorie son appartenance à l'Institut sans cotisation annuelle au niveau nationale. II est bien entendu que le mot "retraite" doit être interprété comme signifiant: l'abandon du travail à temps plein accompagné d'une réduction substantielle de revenu

4.4.2 Examen. Le Conseil de Section vérifie la demande d'un membre de se prévaloir du statut de retraité et recommande ou non l'acceptation de cette demande au Comité exécutif. Dans des cas spéciaux, on peut faire exception à l'obligation d'avoir été membre de l'Institut pendant une période minimale de quinze ans si le Conseil de Section le recommande.

4.4.3 "The Forestry Chronicle" pour les membres retraités. Les membres retraités peuvent recevoir "The Forestry Chronicle" au tarif d'abonnement fixé par le Conseil d'administration et approuvé par les membres de l'Institut. 4.5 Demande d'admission sans faire partie d'une Section 4.5.1 Les demandes d'admission à titre de membre actif, affilié, étudiant ou retraité, qui ne sont pas faites par le truchement d'une Section, doivent être transmises au directeur exécutif qui les soumettra à l'examen du Comité exécutif.

\section{Conseil d'administration}

\subsection{Composition}

5.1.1 Le conseil d'administration est composé d'un représentant de chaque Section ainsi que des membres du Comité exécutif. Tous les administrateurs doivent être membres actifs de l'Institut.

5.2 Nomination des représentants des Sections et des substituts

5.2.1 Mode de nomination. Après l'assemblée générale annuelle de l'Institut, et avant le premier jour de juillet qui suit, chaque Section doit élire ou nommer son représentant au Conseil d'administration. L'élection peut se faire soit par scrutin postal ou à une assemblée générale de la Section ou, si les règlements de la Section le permettent, par nomination du Conseil de la Section. De la même façon chaque Section doit élire un substitut qui remplacera l'administrateur, et jouira des mêmes droits et privilèges, mais seulement si l'absence de ce dernier est inévitable ou dans les circonstances prévues au règlement 5.3. Dans un délai d'un mois après l'élection de l'administrateur et d'un substitut, le Secrétaire de la Section concernée doit aviser le directeur exécutif du résultat de l'élection.

5.2.2 Durée de la fonction. Un administrateur représentant une Section entre en fonction le premier jour de juillet suivant son élection et demeure en poste jusqu'au trentième jour du mois de juin suivant. II peut être réélu.

5.2.3 Dédoublement à éviter. Un membre ne peut agir en même temps comme représentant d'une Section au Conseil d'administration et comme officier élu de l'Institut. Une nomination comme représentant (ou substitut) d'une Section au Conseil devient nulle au moment où la personne entre en fonction à titre de membre du Comité exécutif. Dans un tel cas, la Section concernée élit ou nomme un autre représentant ou un substitut au Conseil. Cette élection ou cette nomination se fait au moins trente jours avant la tenue de l'assemblée générale annuelle subséquente ou, d'après le 
whichever comes first, and may be by resolution either of a Section general meeting or, if this is not feasible, of the Section Council.

5.3 Resignation and Removal

A Directorship may become vacant if the incumbent:

5.3.1 Resigns in writing to the Chairman of the Section.

5.3.2 Does not remain an Active Member.

5.3.3 Is unable to carry on the duties of a Director due to ill health or financial difficulties.

5.3.4 Has assumed office as a Member of the Executive Committee.

5.4 Meetings

5.4.1 Calling of meetings. Meetings of the Board of Directors may be held at any time and place as determined by the Directors, or at the call of the President, providing that fourteen days notice of such meeting shall be sent in writing to each Director. No formal notice shall be necessary if all Directors are present at the meeting or sign written waivers of such notice.

5.4.2 Quorum. A quorum of the Board of Directors is a quorum of the Executive Committee (By-law 6.9.2) plus $50 \%$ of the Section Representatives on the Board.

5.4.3 Decisions. Decisions of the Board shall be made by a simple majority of the votes cast, except when provisions to the contrary are stated elsewhere in these By-laws. In the event of a tied vote the President's decision shall be binding. 5.5 Remuneration and Expenses

Directors, as such, shall not receive any remuneration for their services except as may be prescribed by resolution of the members of the Institute. The Board may resolve for the Institute to reimburse all or any part of the expenses of Directors incurred by their attendance at any meeting of the Board. Nothing herein contained shall be construed so as to preclude any Director from serving the Institute and receiving compensation as an appointed officer or in any other appointed capacity

5.6 Powers, Responsibilities and Indemnification.

5.6.1 The Board of Directors shall manage the property and business of the Institute and may exercise all such powers of the Institute as are not required by the Corporations Act or by these By-laws to be exercised by the Active members at general meetings, or special general meetings or by letter ballot. Within the same limitations the Board may delegate its powers to the Executive Committee as provided by By-law 6.8. 5.6.2 That the Directors of the Institute be and they are hereby authorized to borrow moneys or obtain other financial assistance from time to time from the Bank (including without limitation through the issuance of bills of exchange drawn by the Institute and accepted by the Bank) upon the credit of the Institute in such amounts as they deem proper and by way of overdraft or otherwise.

5.6.3 That any promissory notes, bills of exchange or other negotiable paper (including renewals thereof in whole or in part) signed on behalf of the Institute by the officer or officers of the Institute authorized from time to time to sign negotiable instruments on its behalf and granted to or accepted by the Bank for moneys borrowed and interest thereon as may be agreed upon or other financial assistance obtained from the Bank shall be binding upon the Institute.

5.6.4 That the Directors may from time to time, if they see fit to do so, grant securities by way of mortgage, hypothecation, pledge or otherwise covering all or any of the property and assets of the Institute present and future as security for all or any moneys borrowed by the Institute from the Bank or any other liability of the Institute to the Bank, and any such mortgage, hypothecation, pledge or other security shall be valid and binding upon the Institute if signed by any of the règlement 5.2.1, à la première opportunité; elle peut s'effectuer suivant une décision de l'assemblée générale de la Section ou, si ce n'est pas possible, du Conseil de la Section.

5.3 Démission et déplacement Un siège au Conseil d'administration peut devenir vacant lorsque le titulaire:

5.3.1 Remet sa démission par écrit au président de la Section.

5.3.2 Ne demeure pas membre actif.

5.3.3 Ne peut pas remplir les devoirs d'administrateur pour cause de santé ou de difficultés financières.

5.3.4 Devient membre du Comité exécutif.

5.4 Réunions

5.4.1 Avis de réunions. Les réunions du Conseil d'administration peuvent être tenues à toute date et à tout endroit désigné par les administrateurs, ou à la demande du Président, à la condition qu'un avis écrit ait été envoyé aux administrateurs quatorze jours avant la réunion. Un avis officiel ne sera pas nécessaire si tous les administrateurs sont présents à la réunion ou s'ils renoncent par écrit à recevoir un tel avis.

5.4.2 Quorum. Le quorum du Conseil d'administration est le quorum du Comité exécutif (règlement 6.9.2) plus 50 pourcent des représentants de Section au Conseil.

5.4.3 Décisions. Les décisions du Conseil sont adoptées par la majorité absolue des votes enregistrés, sauf dans les cas où des mesures contraires sont prévues ailleurs dans les présents règlements. En cas d'égalité des votes, le Président aura un vote prépondérant.

5.5 Rémunération et dépenses

Les administrateurs, comme tels, ne recevront aucune rémunération pour leurs services sauf ce qui pourra être établi par résolution des membres de l'Institut. Le Conseil peut décider au nom de l'Institut de rembourser en tout ou en partie les dépenses des administrateurs encourues pour assister à toute réunion du Conseil. Rien de ce qui précède ne doit être interprété comme devant empêcher un administrateur de bien servir l'Institut et de recevoir une compensation à titre d'officier attitré pour toute autre fonction qui lui aurait été assignée.

5.6 Pouvoirs, responsabilités et indemnisations.

5.6.1 Le Conseil d'administration doit administrer les biens et les affaires de l'Institut et peut exercer tous les pouvoirs de I'Institut que la Loi sur les Corporations canadiennes ou les présents règlements ne réservent pas aux membres actifs réunis en assemblée générale, ou en assemblée générale extraordinaire, ou votant par la poste. Compte tenu des mêmes restrictions, le Conseil peut transmettre ses pouvoirs au Comité exécutif comme prévu au règlement 6.8 .

5.6.2 Que les administrateurs de l'Institut soient, et ils le sont par les présentes, autorisés à emprunter de temps à autre de l'argent ou à obtenir de l'aide financière sous d'autres formes de la banque (y compris, sans restriction, par l'émission de lettres de change tirées par l'Institut et acceptées par la banque) sur le crédit de l'Institut, pour les montants qu'ils jugeront convenables, et sous forme d'emprunt à découvert ou autrement.

5.6.3 Que tous les billets à ordre, lettres de change ou autres effets négociables ( $\mathrm{y}$ compris les renouvellements entiers ou partiels de ceux-ci) souscrits au nom de I'Institut par un officier ou des officiers de l'Institut autorisé(s) de temps à autre à souscrire des effets négociables en son nom et donnés ou acceptés par la banque pour des emprunts et l'intérêt tel que convenu ou pour une autre aide financière obtenue de la banque, engagent l'Institut.

5.6.4 Que les administrateurs, s'ils le jugent à propos, puissent donner de temps à autre des garanties, sous forme d'hypothèques, de nantissements, de gages ou autrement engageant la totalité ou une partie des immeubles et des actifs actuels et futurs de l'Institut, en garantie de la totalité ou d'une 
officers authorized to sign negotiable instruments on the Institute's behalf.

5.6.5 All contracts, deeds, grants, assurances and documents reasonably required by the Bank or its Counsel for all or any of the purposes aforesaid shall be executed and carried into effect by the proper officers of the Institute.

5.6.6 This By-law shall be irrevocable until a repealing Bylaw shall have been confirmed or sanctioned by the members and a copy thereof duly certified delivered to the Bank, and meanwhile all the powers and authorities hereby conferred shall continue in force.

5.6.7 The Institute shall indemnify all Directors and Officers of the Institute against, and save them harmless from, all claims, demands, suits, actions, courses of action, costs and expenses, that they incur as a result of being Directors or Officers of the Institute, except arising from their wilful default or negligence.

\section{Executive Committee}

6.1 Composition

The members of the Executive Committee shall be: the President, the Past President, the First Vice-President, and the Second Vice-President.

6.2 Status as Directors

The members of the Executive Committee shall be ex-officio Directors of the Institute.

6.3 Past President

The Past President shall be that member who has most recently completed a term of office as President.

6.4 President

6.4.1 Assumption of Office. The first Vice-President shal automatically become President at the end of the second annual general meeting following his or her election as First Vice-President.

6.4.2 Replacement. If the office of President falls vacant for any reason, the vacancy shall automatically be filled by the First Vice-President who shall continue as President for the remainder of that term. The new President may, at discretion, serve for his or her own term following. If there is no First VicePresident to succeed to the Presidency, then the Second Vice-President shall become Acting President until a new First Vice-President is elected.

6.5 Vice-Presidents

6.5.1 Normal and exceptional circumstances. The First VicePresident and the Second Vice-President normally shall be elected annually by ballot vote of the members as provided for under this By-law, but in exceptional circumstances the Board of Directors may direct an election at the annual, or a special, general meeting, or by a letter ballot.

6.5.2 Election procedure

6.5.2.1 Nominating committee. Each year between the conclusion of the annual general meeting and December 31 next following, the President shall appoint a Nominating Committee of at least three Active Members of the Institute and shall ensure that the Chairman and Secretary of each Section are advised of the composition of the Committee and the mailing address of its Chairman.

6.5.2.2 Nominations. Nominations must be delivered to the Chairman of the Nominating Committee before March 31. Candidacies may be initiated in the following ways:

6.5.2.2.1 By a letter endorsed by six voting members.

6.5.2.2.2 By a letter, certifying a majority vote of a Section at a duly constituted general meeting, signed by the Chairman and the Secretary. partie des emprunts contractés par l'Institut à la banque, ou toute autre obligation de I'Institut envers la banque et toute hypothèque, tout nantissement ou tout gage ainsi donné, est valide et engage I'Institut s'il est souscrit par celui ou ceux des dirigeants autorisés à souscrire les effets négociables pour le compte de l'Institut.

5.6.5 Que tous contrats, actes, documents, concessions et assurances qui sont raisonnablement requis par la dite banque ou ses avocats en ce qui touche toutes ou l'une des fins mentionnées ci-dessus, sont souscrits et mis à exécution par les dirigeants de l'Institut dûment autorisés.

5.6.6 Ce règlement est en vigueur tant qu'un autre règlement l'abrogeant n'aura pas été ratifié ou sanctionné par les membres et qu'un exemplaire dûment certifié soit remis à ladite banque, et dans l'intervalle, tous les pouvoirs et tous les droits conférés, en vertu des présentes, demeurent en vigueur.

5.6.7 L'Institut doit indemniser les administrateurs et les officiers de l'Institut, et les protéger contre toute requête, demande, poursuite, procès, recours en justice, coûts et dépenses, qu'ils peuvent encourir dans l'exercice de leurs fonctions d'administrateurs et d'officiers de l'Institut, sauf en cas de défaut délibéré ou de négligence.

\section{Comité exécutif}

\subsection{Composition}

Le Comité exécutif se compose des membres suivants: le Président, le Président sortant, le premier Vice-Président, et le second Vice-Président.

6.2 Statut d'administrateurs

Les membres du Comité exécutif seront d'office administrateurs de l'Institut.

6.3 Le Président sortant

Le Président sortant est le membre qui a terminé le plus récemment un terme à la présidence.

6.4 Président

6.4.1 Entrée en fonction. Le premier Vice-Président assume automatiquement les fonctions de Président au terme de la seconde assemblée générale annuelle suivant son élection comme premier Vice-Président.

6.4.2 Substitution. Si le poste de Président devient vacant pour une raison quelconque, le premier Vice-Président assume automatiquement cette fonction pour le reste du terme de son prédécesseur et également pour son propre terme comme bon lui semble. S'il n'y a pas de premier VicePrésident pour succéder à la présidence, alors le second Vice-Président assume temporairement le poste de Président jusqu'à l'élection d'un nouveau premier Vice-President.

6.5 Vice-Présidents

6.5.1 Situations normales et exceptionnelles. Le premier Vice-Président et le second Vice-Président sont élus annuellement par voie de scrutin par les membres, tel que défini au présent règlement, mais dans des circonstances exceptionnelles le Conseil d'administration peut tenir une élection à une assemblée générale annuelle ou extraordinaire ou par voie de scrutin postal.

6.5.2 Mode d'élection

6.5.2.1 Comité de nomination. Chaque année après l'assemblée général annuelle et avant le 31 décembre suivant, le Président constitue un Comité de nomination comprenant àu moins trois membres actifs de l'Institut et s'assure que le Président et le secrétaire de chaque Section sont avisés de la formation du comité et de l'adresse postale de son président.

6.5.2.2 Nominations. Les nominations devront parvenir au président du Comité de nomination avant le 31 mars. Les candidatures peuvent être soumises comme suit:

6.5.2.2.1 Par lettre signée par six (6) membres actifs.

6.5.2.2.2 Par lettre signée par le président et par le secrétaire d'une Section certifiant qu'il y a eu scrutin majoritaire lors d'une assemblée dûment convoquée de la Section. 
6.5.2.2.3 By the Nominating Committee in its own right. 6.5.2.3 Examination. The Nominating Committee shall examine each nomination and shall accept those which are in order.

6.5.2.4 Delivery. The Nominating Committee shall, not later than April 30 following its appointment, deliver to the Executive Director at least one nomination for each of the offices of First Vice-President and Second Vice-President, and every such nomination shall be accompanied by the written consent of the nominee to act if elected.

6.5.2.5 Ballot and Announcement of Results.

6.5.2.5.1 The Executive Director shall prepare a ballot if either office is contested. The ballot shall be mailed to all voting members on or before May 15. The ballots shall be returnable to the Head Office not later than June 30 of the same year, in the event that both officers are elected by acclamation a ballot shall not be required, but the results shall be announced as described in Sub-section 6.5.2.5.3.

6.5.2.5.2 In a year when a ballot is required the President shall appoint on or before June 30 two scrutineers to assist the Executive Director in tabulating the results of the ballot.

6.5.2.5.3 On or before July 31 of every year the Executive Director shall announce the results of the elections to all Officers of the Institute, to all Chairmen and Secretaries of the Sections, and to all candidates in the elections. The Executive Director shall also announce the election results to all members at least thirty days before the next ensuing general meeting by a notice in an official publication of the Institute or by direct mail.

6.5.3 Replacement of First Vice-President. If the office of First Vice-President falls vacant without a successor having been elected, an election shall be instigated immediately. This election shall be conducted in accordance with the procedure described in By-law 6.5.2, except that the dates shall be modified as necessary.

6.5.4 Replacement of Second Vice-President. If the office of Second Vice-President falls vacant without a successor having been elected, the Board of Directors shall forthwith elect a Director to that office for the unexpired portion of the current term.

6.6 Term of Office.

The term of office of the members of the Executive Committee shall be from the end of an Annual general meeting until the end of next such meeting. However, a member elected to an office may assume that office immediately if it is vacant. Except as provided in By-law 5.3, the incumbent shall continue to hold office until replaced, as provided for in the Bylaws, or until resignation, whichever event shall occur first.

6.7 Duties

6.7.1 President. The President shall be the Chief Executive Officer of the Institute and shall preside at all meetings of the Institute, of the Board of Directors and of the Executive Committee. The President shall have the general and active management of the business of the Institute and shall see that all orders and resolutions are properly dealt with.

6.7.2 First Vice-President. The First Vice-President shall, in the absence or disability of the President, perform the duties and exercise the powers of the President, and shall perform such other duties as the Board may impose.

6.7.3 Second Vice-President. The Second Vice-President shall, in the absence or the disability of both the President and the First Vice-President perform the duties and exercise the powers of the President and shall perform such other duties as the Board may impose.

6.8 Powers and Limitations

The Executive Committee shall have such powers as may be conferred upon it by resolution of the Board of Directors and of general meetings, by letter ballot, and through these By-laws.
6.5.2.2.3 Le Comité de nomination lui-même.

6.5.2.3 Examen. Le Comité de nomination doit vérifier chaque nomination et accepter celles qui sont conformes aux règlements.

6.5.2.4 Rapport. Le Comité de nomination doit au plus tard le 30 avril suivant sa convocation, remettre au directeur exécutif le nom d'au moins un candidat aux postes de premier VicePrésident et de second Vice-Président, et chaque candidature doit être accompagnée d'une lettre signée par le candidat affirmant qu'il acceptera le poste s'il est élu.

6.5.2.5 Bulletin de vote et annonce des résultats.

6.5.2.5.1 Le directeur exécutif prépare un bulletin de vote s'il y a plus d'un candidat à l'un ou l'autre des postes. Le bulletin de vote est posté à tous les membres ayant droit de vote le ou avant le 15 mai. Les bulletins de vote doivent être retournés au siège social avant le 30 juin de la même année. Lorsque les deux officiers sont élus par acclamation, un bulletin de vote n'est pas nécessaire mais les résultats sont annoncés, tel que prévu au règlement 6.5.2.5.3.

6.5.2.5.2 Lorsque le vote est nécessaire, le Président désignera le ou avant le 30 juin, deux scrutateurs pour aider le directeur exécutif, à dépouiller le scrutin.

6.5.2.5.3 Le ou avant le 31 juillet de la même année, le directeur exécutif fait part du résultat de l'élection à tous les candidats à l'élection, à tous les officiers de l'Institut et au présidents et aux secrétaires de toutes les Sections. Le directeur exécutif doit aussi transmettre les résultats de l'élection à tous les membres au moins trente (30) jours avant l'assemblée générale subséquente, par avis dans une publication officielle de l'Institut ou par courrier.

6.5.3 Substitution du premier Vice-Président. Si le poste de premier Vice-Président devient vacant avant qu'un successeur ne soit élu, une élection doit être tenue immédiatement. Cette élection est conduite suivant la procédure décrite au règlement 6.5 .2 mais les dates sont modifiées si nécessaire.

6.5.4 Substitution du second Vice-Président. Si le poste de second Vice-Président devient vacant sans qu'un successeur n'ait été élu, le Conseil d'administration élit aussitôt un administrateur à ce poste pour le reste du terme en cours.

6.6 Durée du mandat. La durée du mandat des membres du Comité exécutif s'étend de la fin de l'assemblée générale annuelle jusqu'à la fin de l'assemblée suivante. Cependant, un membre élu à un poste peut accéder à ce poste immédiatement s'il est vacant. Sauf dans le cas prévu au règlement 5.3 , le titulaire continue à occuper le poste jusqu'à l'élection de son successeur, tel que prévue au présent règlement, ou jusqu'à ce qu'il résigne selon la première éventualité

6.7 Devoirs

6.7.1 Le Président. Le Président est l'administrateur en chef de l'Institut et il préside toutes les assemblées de l'Institut, du Conseil d'administration et du Comité exécutif. II a la direction générale et active des affaires de l'Institut et il voit à ce que toutes les directives et résolutions soient acquittées de la meilleure façon.

6.7.2 Premier Vice-Président. Le premier Vice-Président doit, en cas d'absence ou d'incapacité du Président, accomplir les devoirs et exercer les pouvoirs du Président et accomplir toute autre tâche que le Conseil peut lui imposer. 6.7.3 Second Vice-Président. Le second Vice-Président doit en cas d'absence ou d'incapacité du Président et du premier Vice-Président, accomplir les devoirs et exercer les pouvoirs du Président et accomplir toute autre tâche que le Conseil peut lui imposer.

6.8 Pouvoirs et restrictions

Le Comité exécutif a les pouvoirs qui lui sont attribués par résolution du Conseil d'administration et des assemblées générales, par scrutin postal et d'après les présents règlements.

6.8.1 Pouvoirs attribués par le Conseil d'administration. Les pouvoirs attribués au Comité exécutif par le Conseil 
6.8.1 Powers from the Board of Directors. Power conferred upon by the Executive Committee by the Board of Directors shall not exceed those of the Board itself and shall not conflict with the provisions of these By-laws. Powers thus conferred may be revoked or amended by resolution of the Board or of a general meeting.

6.8.2 Powers from general meetings. A general meeting may confer upon the Executive Committee any powers which do not conflict with these By-laws, and such powers may be revoked or amended only by another resolution of a general meeting.

6.8.3 Powers from letter ballot as per By-law 9.3.

6.8.4 Extraordinary circumstances.

6.8.4.1 In exceptional circumstances and when the good of the Institute requires, the Executive Committee members may exercise extraordinary powers, according to their collective competence and wisdom, and initiate action.

6.8.4.2 Such action must be communicated to the Board of Directors forthwith for consideration.

6.8.4.3 A two-thirds majority vote of the Board shall constitute approval.

6.8.4.4 These decisions must be made known to the members and upon the decision of the Board of Directors may be put to referendum or reported at a subsequent annual general meeting

6.9 Meetings

6.9.1 Calling of meetings. The Executive Committee shall meet at the call of the President or the First Vice-President acting in the capacity of President.

6.9.2 Quorum. Either the President or the First VicePresident and one other of its members shall constitute a quorum of the Executive Committee.

\section{Appointed Officers. Agents and Employees}

\subsection{Appointed Officers}

7.1.1 Definition. The Executive Director and the Editor are under contract as officers of the Institute and must be members of the Institute.

7.1.2 Appointment. The contract with the Executive Director (Contractor) shall be for a period not exceeding three years, and renewable for a like period. Notwithstanding, the contract may be terminated at any time and for just cause by the Institute or the Contractor

7.1.3 The contract with the Editor shall be for a period not exceeding one year and is renewable annually.

7.1.4 Appointments and terminations of officers under contract must be confirmed by the Board of Directors.

7.1.5 Substitution. In the absence of or in the disability of any appointed Officer, the Executive Committee may appoint a temporary replacement.

\subsection{Duties of the Executive Director}

7.2.1 Financial

7.2.1.1 The Executive Director shall have the custody of the Institute's funds and securities and shall keep full and accurate accounts of receipts and disbursements in books belonging to the Institute, and shall deposit all moneys and other valuable effects in the name and to the credit of the Institute and in such depositories as may be designated by the Board of Directors from time to time.

7.2.1.2 The Executive Director shall disburse the funds of the Institute as may be ordered by the Board, taking proper vouchers for such disbursements, and shall render to the President and Directors at the regular meetings of the Board. or whenever they require it, an account of all fiscal transactions on behalf of the Institute and of the financial position of the Institute.

7.2.1.3 The Executive Director shall present to the Board before each annual general meeting a proposed final budget d'administration ne doivent pas dépasser ceux du Conseil luimême et ne doivent pas être contraires aux prescriptions des présents règlements. Les pouvoirs ainsi attribués peuvent être révoqués ou amendés par résolution du Conseil d'administration ou d'une assemblée générale.

6.8.2 Pouvoirs attribués par résolution d'une assemblée générale. Le Comité exécutif peut recevoir lors d'une assemblée générale certains pouvoirs qui ne doivent pas entrer en conflit avec les présents règlements, et de tels pouvoirs ne peuvent être révoqués ou amendés que par une autre résolution d'une assemblée générale.

6.8.3 Pouvoirs attribués par scrutin postal tel qu'indiqué au règlement 9.3 .

6.8.4 Circonstances extraordinaires.

6.8.4.1 Dans des circonstances extraordinaires et pour le plus grand bien de l'Institut, les membres du Comité exécutif peuvent exercer des pouvoirs extraordinaires et prendre action en se basant sur leur compétence et sur leur expérience collective

6.8.4.2 Le Conseil d'administration doit être informé sur-lechamp de telles initiatives.

6.8.4.3 Une majorité des deux-tiers des votes du Conseil constitue une approbation.

6.8.4.4 Ces initiatives doivent être communiquées aux membres et sur décision du Conseil d'administration, peuvent faire l'objet d'un référendum ou d'un rapport à une assemblée générale annuelle subséquente.

6.9 Réunions.

6.9.1 Avis de réunions. Le Comité exécutif se réunit à la demande du Président ou du premier Vice-Président agissant en tant que Président.

6.9.2 Quorum. Le Président ou le premier Vice-Président et un autre membre constituent le quorum du Comité exécutif.

\section{Engagement des officiers, agents et employés}

7.1 Engagement d'officiers

7.1.1 Définition. Le directeur exécutif et l'éditeur sont engagés par contrat à titre d'officiers de l'Institut et doivent être membres de l'Institut.

7.1.2 Engagement. Le contrat avec le directeur exécutif (contracteur) a une durée qui n'excède pas trois ans, et est renouvelable pour une période similaire. Toutefois, le contrat peut être résilié en tout temps et pour une bonne cause, par I'Institut ou par le contracteur.

7.1.3 Le contrat avec l'éditeur a une durée qui n'excède pas une année et il est renouvelable annuellement.

7.1.4 Le début et la fin de l'engagement des officiers sous contrat sont entérinés par le Conseil d'administration.

7.1.5 Remplacement. Advenant que I'un des officiers précités devienne incapable de remplir sa fonction pour une raison ou pour une autre. le Comité exécutif peut nommer un remplaçant temporaire.

7.2 Responsabilités du directeur exécutif.

7.2.1 Finance.

7.2.1.1 Le directeur exécutif a la garde des fonds et des valeurs de l'Institut. II doit tenir dans les livres de l'Institut des comptes précis et complets des sommes perçues et dépensées, il doit également déposer tous les argents et autres valeurs au nom et au crédit de l'Institut chez les dépositaires désignés de temps à autre par le Conseil d'administration.

7.2.1.2 Le directeur exécutif doit, selon les instructions émises à ce sujet par le Conseil, débourser les argents de I'Institut et garder les pièces justificatives à cette fin. Lors des assemblées régulières du Conseil d'administration ou à la demande du Président et des administrateurs, il doit leur rendre compte de toutes les transactions financières exécutées au nom de l'Institut et aussi les informer de la situation financière de l'Institut.

7.2.1.3 Le directeur exécutif doit, avant chaque assemblée générale annuelle, présenter au Conseil le budget final 
for the current financial year and a preliminary budget estimate for the ensuing financial year.

7.2.1.4 The Executive Director shall give to the Institute a bond for the faithful performance of the duties of the office and for the restoration to the Institute in the event of his or her death, resignation, retirement or removal from office of all books, papers, vouchers, money and other property of whatever kind in the possession or under the control of the Executive Director, or which may have been disposed of improperly, or which may have disappeared without adequate explanation. Such bond shall be of such form, amount and surety as are acceptable to the Board.

7.2.2 Secretarial and general. The Executive Director shall attend, and shall act as clerk of, all meetings of the Board of Directors and of the Institute at the pleasure of the members. The duties as clerk shall be to record all votes and minutes of all proceedings in the books to be kept for that purpose. The incumbent shall give, or cause to be given, notice of all meetings of the members, and of the Board. Within thirty days of the election of each Officer and Director the Executive Director shall supply them with copies of all resolutions then operative pertaining to the duties and responsibilities of the Executive Committee. The Executive Director shall be under the direct supervision of the President, although ultimately answerable to the Board of Directors as described elsewhere in this By-law 7.

7.2.3 Policy and Program. Acting under the guidance and direction of the Executive Committee, the Executive Director will be responsible for implementation of policy and program initiatives and for liaison with governments, the Institute's Sections, Committees and Working Groups, other Associations and the Editor and printer of the Forestry Chronicle.

7.2.4 The Executive Director shall produce financial statements and records for examination by the Finance Committee as required for it to conduct its normal duties.

7.2.5 Custody of seal. The Executive Director shall be the custodian of the seal of the Institute, which shall be delivered to another person or persons only as and when authorized by the Executive Committee.

\subsection{Agents and Employees}

The Executive Committee may appoint agents and engage employees and enter into contract with individuals who shall have such authority and duties as the Committee prescribes. 7.4 Remuneration

The remuneration of appointed Officers, agents and employees shall be fixed by resolution of the Executive Committee subject to endorsement by the Board of Directors.

\section{Financial Year}

8.1 The financial year of the Institute shall be the period from the first day of July to the thirtieth day of June next.

\section{Meetings and Voting}

\subsection{Meeting Arrangements}

9.1.1 Calling of meetings. The Board of Directors shall determine the time and place of any annual or special general meeting of the Institute, and thirty days written notice shall be given to all classes of members.

9.1.2 Annual general meeting. The annual general meeting of the Institute shall be held not earlier than August 1 and not later than November 30, except that under exceptional circumstances these deadlines may be waived at the direction of the Board of Directors.

9.1.3 Special meetings. A special general meeting maybe called, upon a formal request by a Section Council acting on a Resolution approved at a duly constituted general meeting of the Section, or following a written request endorsed by thirtyfive voting members of the Institute. proposé pour l'exercice financier en cours et aussi une estimation budgétaire préliminaire pour l'année suivante.

7.2.1.4 Le directeur exécutif doit fournir à l'Institut une police fidélité garantissant qu'il s'acquittera fidèlement des devoirs rattachés à sa fonction et qu'advenant son décès, sa démission forcée ou volontaire, ou sa mise à la retraite tous les livres, papiers, pièces justificatives, argents ou les autres effets qui étaient en sa possession ou sous son contrôle ou qui pourraient avoir disparu sans raison valable ou dont il aurait disposé malhonnêtement seront retournés à l'Institut. La nature, le montant et l'étendue de la police fidélité exigée du directeur exécutif sont sujets à l'approbation du Conseil d'administration.

7.2.2 Secrétariat et généralités. Le directeur exécutif doit assister à toutes les réunions du Conseil d'administration et de I'Institut au bon plaisir des membres. II agit alors comme secrétaire et il doit consigner tous les votes et résumer les délibérations dans les livres gardés à cette fin. II doit aviser ou faire aviser les membres et le Conseil d'administration et de la tenue d'assemblées. Durant les trente jours suivant l'élection de chaque officier ou de chaque administrateur, il doit fournir à ces derniers des copies de toutes les résolutions alors en force se rapportant aux devoirs et responsabilités du Comité exécutif. Le directeur exécutif sera directement responsable au Président; toutefois, il se rapporte en dernier recours au Conseil d'administration tel que décrit ailleurs dans ce règlement 7 .

7.2.3 Politique et programme. Agissant sous la gouverne et la direction du Comité exécutif, le directeur exécutif est responsable de la mise en oeuvre de la politique et des programmes de l'Institut, et de la liaison avec les gouvernements, les Sections de l'Institut, les comités et groupes de travail, les autres associations, l'éditeur et l'imprimeur du "Forestry Chronicle".

7.2.4 Le directeur exécutif produit les états financiers et les documents pertinents, et il les soumet à l'attention du comité des finances de façon à ce que celui-ci puisse s'acquitter normalement de ses devoirs.

7.2.5 Garde du sceau. La directeur exécutif a la garde du sceau de l'Institut. II peut remettre le garde du sceau à une autre personne ou à d'autres personnes seulement lorsqu'il est autorisé à le faire par le Comité exécutif.

7.3 Agents et employés.

Le Comité exécutif peut nommer des agents et engager des employés dont l'autorité et les fonctions sont définies par le dit comité.

7.4 Rénumération

La rémunération des officiers, agents ou employés nommés ou engagés, est fixée par résolution du Comité exécutif, sujette à l'approbation du Conseil d'administration.

\section{Exercice financier}

8.1 L'exercice financier de l'Institut s'étend du premier jour de juillet au trentième jour de juin suivant.

\section{Assemblées et votes}

\subsection{Modalités des assemblées}

9.1.1 Convocation des assemblées. Le Conseil d'administration détermine la date et l'endroit de toute assemblée générale annuelle ou extraordinaire de l'Institut et un avis écrit de trente jours doit être envoyé aux membres de toutes les catégories.

9.1.2 Assemblée générale annuelle. L'assemblée générale annuelle de l'Institut ne doit pas être tenue plus tôt que le 1 er août ni plus tard que le 30 novembre; le Conseil d'administration peut changer ces dates dans des circonstances exceptionnelles.

9.1.3 Assemblées extraordinaires. Une assemblée générale extraordinaire peut être convoquée sur demande expresse du Conseil d'une Section donnant suite à une résolution approuvée en bonne et due forme par l'assemblée générale 
9.2 Quorum and Voting

9.2.1 Quorum. Thirty-five voting members present in person at a general meeting shall constitute a quorum.

9.2.2 Voting Rights. Only Active members may vote in the affairs of the Institute. Each Active member present at a general meeting shall have the right to exercise one vote except that an Active member may appoint, in writing, any other Active member present at the meeting to vote as proxy. 9.2.3 Voting and majority decision. At all meetings of the members of the Institute every question shall be determined by a majority of votes unless otherwise specifically provided by the Corporations Act, or by these By-laws. Voting shall be by a show of hands or a ballot as required by the Board of Directors or the Chairman of the meeting, except as described in By-law 9.3.

9.3 Letter Ballot

9.3.1 Authorization. The Board of Directors may direct the preparation, circulation and scrutiny of a letter ballot to obtain the wishes of the voting members upon a choice of policy or a line of action except where the Canada Corporations Act prescribes the holding of a meeting of members. Any such letter ballot shall state whether the results are intended to be binding primarily upon the membership as a whole, or on the Board of Directors in the performance of its duties.

9.3.2. Communication and application of resolutions. The Executive Director shall communicate the results to the membership without undue delay through the Section Chairmen and the Directors and through a notice in the next issue of an official publication of the Institute where-upon these results shall be binding upon the parties concerned.

9.4 Procedure.

In all cases not otherwise provided for in the By-laws. "Robert's Rules of Order Revised" shall govern the proceedings of all meetings of the Institute.

\section{Auditors}

10.1 At each annual general meeting the Board of Directors shall recommend for appointment by the Active members present an Auditor or Auditors, to audit the account of the Institute and to hold office until the next annual general meeting, except that any unforeseen vacancy in the office of Auditor may be filled by appointment of the Executive Committee. The remuneration of the Auditor, or Auditors shall be fixed by the Executive Committee within the budget of the Institute.

\section{Signing and Certifying of Documents \\ 11.1 Signing Officers}

Contracts, documents, or any instruments in writing requiring the signature of the Institute shall be signed by any two of the President, First Vice-President Second Vice-President, Past President or Executive Director, and shall then be binding upon the Institute without further authorization or formality.

11.2 Special Appointment of Signing Officers

The Board of Directors may, as necessary, appoint by resolution an Officer, or Officers to sign specific contracts, documents and instruments in writing on behalf of the Institute; the seal of the Institute may be fixed to such signed articles when required.

\section{Board of Examiners}

\subsection{Composition and Appointment}

12.1.1 The Board of Examiners shall consist of four members of whom three shall be appointed by the Executive Committee for a term of three years in such a manner that one member retires and is replaced at the end of each annual de la Section, ou à la suite d'une demande écrite endossée par trente-cinq membres votant de l'Institut.

9.2 Quorum et vote

9.2.1 Quorum. Trente-cinq membres votants présents en personne à une assemblée générale constituent le quorum. 9.2.2 Seuls les membres actifs peuvent voter sur les questions d'affaires de l'Institut. Tout membre actif présent à une assemblée générale a le droit d'exercer un vote mais un membre actif peut déléguer, par écrit, un autre membre actif présent à l'assemblée, comme fondé de pouvoir.

9.2.3 Vote et décision majoritaire. A toute assemblée des membres de l'Institut, toute décision est déterminée par la majorité des votes à moins qu'il n'en soit spécifié autrement dans la Loi sur les Corporations canadiennes, ou dans les présents règlements. Le vote peut se faire à main levée ou par scrutin tel que requis par le Conseil d'administration ou par le Président de l'assemblée, sauf pour les cas prévus au règlement 9.3 .

\subsection{Scrutin postal}

9.3.1 Autorisation. Le Conseil d'administration peut ordonner la préparation, l'expédition et le dépouillement d'un scrutin par la poste afin de recueillir l'opinion des membres votants sur une question de politique ou sur une ligne de conduite à adopter sauf lorsque la Loi sur les Corporations canadiennes exige la tenue d'une assemblée des membres. Un tel scrutin postal doit spécifier si les résultats engagent principalement tous les membres. ou le Conseil d'administration dans l'accomplissement de ses devoirs.

9.3.2 Communication et mise à exécution des résolutions. Le directeur exécutif communiquera sans délai les résultats aux membres par l'entremise des présidents de Sections et des administrateurs et par un avis dans le prochain numéro d'une publication officielle de l'Institut après quoi les résultats engageront les parties en cause.

9.4 Procédure

Dans tous les cas non prévus aux règlements, la plus récente édition de "Robert's Rules of Order Revised" régit les débats de toutes les réunions de l'Institut.

\section{Vérificateurs}

10.1 Lors de l'assemblée générale annuelle, le Conseil d'administration doit proposer aux membres actifs présents la nomination d'un ou des vérificateurs pour examiner les livres de l'Institut avec mandat effectif jusqu'à l'assemblée générale annuelle subséquente; toute vacance imprévisible au bureau du vérificateur peut être comblée par la nomination d'un remplaçant par le Comité exécutif. La rémunération du ou des vérificateurs est fixée par le Comité exécutif à même le budget de l'Institut.

\section{Signature et attestation des documents \\ 11.1 Signataires}

Les contrats, documents ou tout autre écrit nécessitant la signature de l'Institut, doivent être signés par deux des personnes suivantes: le Président, le premier Vice-Président ou le directeur exécutif et alors, ils lient l'Institut sans autre autorisation ou formalité.

11.2 Nomination spéciale de signataires.

Le Conseil d'administration peut, en cas de nécessité, désigner par résolution un ou des administrateurs pour signer au nom de l'Institut des contrats, documents et écrits spécifiques; le sceau de I'Institut peut être apposé à ces signatures lorsque requis.

\section{Bureau des examinateurs}

\subsection{Composition et nomination}

12.1.1 Le Bureau des examinateurs est composé de quatre membres dont trois sont désignés par le Comité exécutif pour un terme de trois ans de telle manière qu'un membre se retire et soit remplacé à la fin de chaque assemblée générale annuelle. 
general meeting. If a member does not complete the term of office a replacement may be appointed for the remainder of that term.

12.1.2 The appointed member who has served two years on the Board of Examiners shall normally become Chairman in his or her third year. Failing this, appointment to such office shall be made by the Executive Committee.

12.1.3 The Executive Director shall, ex-officio, be the fourth member of the Board.

12.2 Duties

The duties of the Board of Examiners shall be to examine the qualification of those applying for membership in the Institute as and when prescribed in By-law 3, and also to examine the qualifications of any applicant in case of uncertainty.

\section{Sections}

\subsection{Establishment}

13.1.1 Application by members. The basis of forming a new Section shall be an application by at least fifty voting members made to the Board of Directors requesting the formation of a Section in the area in which they work and reside.

13.1.2 Establishment by directors. The Board of Directors may, by resolution, establish Sections in such areas and with such functions, regulations and limitations as they see fit.

13.2 Membership

The qualification for membership in a Section shall be membership in the Institute.

\subsection{Section Council}

13.3.1 Composition and duties. The affairs of a Section shall be managed by a Council consisting of a Chairman, a ViceChairman, a Secretary-Treasurer or a Secretary and Treasurer, the Section Representative on the Board of Directors, and not less than two additional members. The Chairman and the Vice-Chairman of the Section and the Section Representative on the Board of Directors shall be Active members of the Institute. If shall be the responsibility of the Chairman and the Secretary-Treasurer to maintain contact with the Officers of the Institute.

13.3.2 Appointment. The members of the Council shall be members of the Section and shall, with the exception of the Secretary-Treasurer, be elected by ballot of the members of the Section. They shall be elected each year, or every other year, according to the regulations adopted by the Section, and shall hold office until the end of the fiscal year of the Section, or until such date as their successors have been declared elected. The Section Representative on the Board of Directors and the Alternate shall be elected as provided by By-law 5.2. The Secretary-Treasurer shall be appointed by the Section Council each year and shall hold office until the appointment of a successor.

13.3.3 Meeting and quorum. Meetings of a Section Council may be held at anytime and place as determined by the members of the Council, provided that four days notice of such meeting shall be sent in writing to each Council member. Half of the members of the Council shall constitute a quorum. 13.4 Annual Meeting

A Section shall hold an annual meeting, preferably in the spring, at which the members shall receive a report of the Council.

\subsection{Dues}

A Section may collect from its members, for its own use, such dues as are determined at a general meeting of the Section. 13.6 Commitment of the Institute

A Section may not commit the Institute by its actions.

13.7 Rules and Regulations

A Section may adopt such rules and regulations for its own government as are not inconsistent with these By-laws.
Si un membre ne peut compléter son mandat, un remplaçant peut être désigné pour compléter son mandat.

12.1.2 Le membre qui a siégé depuis deux ans au Bureau des examinateurs en est normalement le Président à la troisième année. A défaut, le Comité exécutif doit nommer un autre membre.

12.1.3 Le directeur exécutif est membre d'office de ce comité.

12.2 Fonctions.

Les fonctions du Bureau des examinateurs sont d'examiner les titres des personnes désirant devenir membres de l'Institut selon les prescriptions du règlement 3 , et aussi d'examiner les titres de tout candidat où il y a incertitude.

\section{Sections}

13.1 Création

13.1.1 Requête par les membres. La demande initiale en vue d'obtenir la formation d'une nouvelle Section doit consister en une requête signée par au moins cinquante membres en règle, faite au Conseil d'administration demandant la création d'une Section dans le territoire de leur lieu de travail et de résidence.

13.1.2 Création par les administrateurs. Le Conseil d'administration peut, par résolution, créer des Sections à certains endroits pour des fins précises et en déterminer les règlements et les restrictions qu'ils jugent à propos.

13.2 Membre

II faut être membre de l'Institut pour devenir membre d'une Section.

\subsection{Conseil de la Section}

13.3.1 Composition et devoirs. Les affaires de la Section doivent être administrées par un Conseil se composant d'un président, d'un vice-président, d'un secrétaire-trésorier ou d'un secrétaire et d'un trésorier, d'un représentant de la Section au Conseil d'administration et de deux membres additionnels. Le président, le vice-président de la Section et le représentant de la Section au Conseil d'administration, doivent être des membres actifs de l'Institut. Le président et le secrétaire-trésorier sont responsables du maintien des relations avec les officiers de l'Institut.

13.3.2 Nominations. Les membres du Conseil doivent être membres de la Section et doivent, à l'exception du secrétairetrésorier, être élus au scrutin par les membres de la Section. Ils doivent être élus chaque année ou à tous les deux ans, selon les règlements adoptés par la Section, et ils doivent demeurer en fonction jusqu'à la fin de l'année fiscale de la Section ou jusqu'au moment où leurs successeurs ont été déclarés élus. Le représentant de la Section au Conseil d'administration et son substitut doivent être élus tel que prévu au règlement 5.2. Le secrétaire-trésorier doit être nommé chaque année par le Conseil de la Section et doit demeurer en fonction jusqu'à la nomination d'un successeur.

13.3.3 Réunion et quorum. Les réunions du Conseil de la Section peuvent être tenues à la date et au iieu établis par les membres du Conseil en autant qu'un avis de la tenue d'une telle réunion soit envoyé par écrit à chacun des membres du Conseil quatre jours à l'avance. La moitié des membres du Conseil forment le quorum.

13.4 Assemblée annuelle

Une Section doit tenir une assemblée annuelle de preférence au printemps; le Conseil fait alors rapport des activités.

13.5 Cotisations

Une Section peut percevoir de ses membres, pour ses propres besoins, une cotisation telle qu'établie a une assemblée générale de la Section.

13.6 Engagement de I'Institut

Une Section ne peut pas engager l'Institut par ses actions.

13.7 Réglementation

Une Section peut adopter des règlements et règles de pratique pour sa propre gouverne en autant qu'ils ne sont pas en contradiction avec les règlements de l'Institut. 


\section{Rules and Regulations}

14.1 The Board of Directors may recommend changes and amendments to the rules and regulations as they deem fit for the proper management and operation of the Institute. Such changes of the rules and regulations must not be inconsistent with these By-laws and shall have effect until the next annual general meeting of the Institute when they shall be ratified, repealed or amended by the membership. If ratified, with or without amendments, they shall have effect until further amended or repealed as herein described.

\section{By-Laws}

\subsection{Amendment}

15.1.1 The Board of Directors may recommend changes and amendments to the By-laws. Such changes must be confirmed at a general meeting, duly called for that purpose, or by a letter ballot as directed by the Board of Directors. A letter ballot shall be conducted by the Executive Director with the assistance of two scrutineers appointed by the President, and there shall be at least six weeks between the dates when ballots are mailed out and when the ballot is closed. An affirmative vote for changes to the By-laws shall be at least two-thirds of the Active members voting.

15.1.2 Approved changes of the By-laws shall be communicated to the membership without undue delay through the Section Chairmen and the Directors and through a notice in the next issue of an official publication of the Institute. 15.1.3 Changes of the By-laws shall not take effect until approval of the Corporations Branch, Department of Consumer and Corporate Affairs, has been obtained.

\section{Translation}

16.1 The By-laws are published in English and French. In the case of difficulty in interpretation, the English version is regarded as authoritative.

\section{Règles de pratique}

14.1 Le Conseil d'administration peut recommander des changements et des amendements aux règles de pratique s'il le juge à propos pour l'administration et la conduite efficace des affaires de l'Institut. De telles règles ne doivent pas être en contradiction avec les règlements et demeurent en vigueur jusqu'à l'assemblée générale annuelle subséquente de l'Institut alors qu'elles sont ratifiées, rejetées ou amendées par les membres. Si ratifiées avec ou sans amendement, elles sont en vigueur jusqu'à ce qu'elles soient à nouveau amendées ou révoquées selon la procédure décrite ici.

\section{Règlements}

15.1 Amendement

15.1.1 Le Conseil d'administration peut recommander des changements et des amendements aux règlements. De tels changements doivent être approuvés par une assemblée générale dûment convoquée à cette fin, ou par scrutin postal, tel que décidé par le Conseil d'administration. Un scrutin doit être tenu par le Dircteur exécutif avec l'aide de deux scrutateurs nommés par le Président; au moins six semaines devront s'écouler entre la date d'envoi des bulletins de vote par la poste et celle de la fin du scrutin. Un vote favorable au changement des règlements doit représenter au moins les deux-tiers des membres actifs ayant voté.

15.1.2 Les changements de règlements approuvés doivent être communiqués aux membres aussitôt que possible par le président de Section et les administrateurs et aussi au moyen d'un avis placé dans le prochain numéro d'une publication officielle de l'Institut.

15.1.3 Les changements aux règiements ne peuvent prendre effet qu'après avoir été approuvés par le Bureau des Corporations du Ministère de la Consommation et des Corporations.

\section{Traduction}

16.1 Les règlements généraux sont publiés en anglais et en français. En cas de difficulté d'interprétation, la version anglaise est officielle.

Texte traduit de l'anglais par G. Paillé et revu par C. Turmel F. Matte et François Sauvageau.

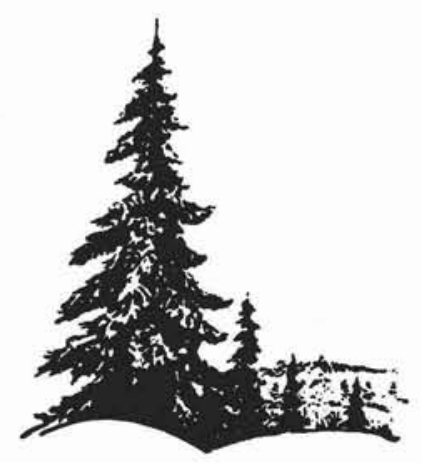




\section{Canadian Institute of Forestry Rules and Regulations}

\section{Committees and Working Groups}

1.1. Executive Committee (Elected - Ref. By-law 6.5.2.)

1.1.1. The Executive Committee shall guide, direct and otherwise assist the Executive Director in conducting the affairs ot the Institute.

1.1.2. The Executive Committee shall act as a Trustee Board for the administration of Pension Funds established for the benefit of employees of the Institute.

1.1.3. At least three meetings of the Executive Committee shall be held each year.

1.2. National Committees and Boards (appointed)

1.2.1. National Committees and Boards will consist of Technical-Affairs Committees, Institute Affairs Committees and Special Committees.

1.2.2. National Committees and Boards may be established from time to time by the Board of Directors or the Executive Committee.

1.2.3. Chairmen of Committees and Boards will be appointed by the President.

1.2.4. Terms of office may be established by mutual agreement between the President and the Committee or Board Chairman, and are renewable on the mutual agreement of the Board of Directors and the Chairman concerned.

1.2.5. Terms of reference may be established by the Board of Directors, the Executive Committee, the President in consultation with the Committee or Board Chairman or as outlined in the By-laws or these Rules and Regulations. Specific terms of reference will be made at the time of, or prior to, establishment of committees or Boards.

1.2.6. Members of Committees and Boards will be appointed by the President in consultation with the Committee or Board Chairman.

1.2.7. Terms of reference and Committee and Board membership shall be reviewed by the Executive Committee regularly and by the Board of Directors annually.

1.2.8. Institute funds may be authorized by the Executive Committee to finance Committee or Board projects.

1.2.9. Every Committee or Board will submit a written report for the Board of Directors, to the Executive Director seven weeks prior to each Annual Meeting. Committee or Board Chairmen will report to the Executive Committee on request. 1.2.10. The Executive Director is an ex-officio member of all appointed National Committees and Boards.

1.2.11. Any appointed committee or Board may be discharged by the Board of Directors, normally at the end of an Annual Meeting.

1.3. Technical Affairs Committee

1.3.1. Terms of office will normally be three years.

1.3.2. General terms of reference are:

1.3.2.1. To report on developments and progress in forest oriented activities

1.3.2.2. To stimulate thought, study and discussion.

1.3.2.3. To suggest means by which the practice of forestry may be improved and strengthened.

1.3.2.4. To assist in locating speakers for and arranging sessions at meetings.

1.4. Institute Affairs Committees and Boards

1.4.1. Terms of office will normally be one year.

1.4.2. General terms ot reference are:

1.4.2.1. To facilitate Institute business.

1.4.2.2. To improve administration.

1.4.2.3. To improve efficiency.

1.4.2.4. To improve or increase activities.

1.4.2.5. To improve or increase the effectiveness of the Institute.

\section{Institut Forestier du Canada Règles de Pratique}

\section{Comités et groupes de travail}

1.1. Comité exécutif (Elu - Réf. Règlements (6.5.2)

1.1.1. Le Comité exécutif guide, dirige et en tout assiste le directeur exécutif en place dans la conduite des affaires de I'Institut.

1.1.2. Le Comité exécutif agit comme curateur du fonds de pension établi pour les employés de l'Institut.

1.1.3. Le Comité exécutif se réunit au moins trois fois par année.

1.2. Comités et conseils nationaux (institués).

1.2.1. Les comités et conseils nationaux sont: le Comité des Affaires techniques, le Comité des Affaires de l'Institut, des comités spéciaux (ad hoc).

1.2.2. Les comités et conseils nationaux peuvent être formés de temps à autre par le Conseil d'administration ou le Comité exécutif.

1.2.3. Les présidents de comités et conseils sont nommés par le Président.

1.2.4. La durée d'exercice peut être établie après entente mutuelle entre le Président et le président du comité ou conseil et elle est renouvelable après entente mutuelle entre le Conseil d'administration et le président du comité ou conseil concerné.

1.2.5. Le mandat peut être établi par le Conseil d'administration, le Comité exécutif, le Président après consultation avec le président du comité ou conseil, ou tel que défini par les règlements ou les présentes règles de pratique. Un mandat spécifique est établi au moment de, ou avant la formation des comités ou conseils.

1.2.6. Les membres des comités et conseils sont nommés par le Président après consultation avec le président de chaque comité ou conseil.

1.2.7. Le mandat et la liste des membres des comités et conseils sont revus régulièrement par le Comité exécutif et annuellement par le Conseil d'administration.

1.2.8. Le Comité exécutif peut allouer des fonds de l'Institut pour le financement des activités des comités et conseils.

1.2.9. Chaque comité et conseil présente un rapport écrit au directeur exécutif pour étude par le Conseil d'administration au moins sept semaines avant chaque assemblée annuelle. Les présidents de comités et conseils font rapport au Comité exécutif sur demande.

1.2.10. Le directeur exécutif est d'office un membre de tous les comités et conseils nationaux institués.

1.2.11. Tout comité ou conseil institué peut normalement être dissout par le Conseil d'administration à la fin de l'assemblée annuelle.

1.3. Comités des Affaires techniques.

1.3.1. La durée d'exercice est normalement de trois ans.

1.3.2. Les mandats consistent généralement à:

1.3.2.1. Faire le compte rendu des développements et des progrès dans le domaine forestier.

1.3.2.2. Encourager la réflexion, la recherche et la discussion.

1.3.2.3. Suggérer les moyens susceptibles d'améliorer et de renforcer la pratique de la foresterie.

1.3.2.4. Prêter assistance dans l'organisation de réunions et suggérer des conférenciers.

1.4. Comités et conseils des Affaires de l'Institut

1.4.1. La durée d'exercice est normalement d'un an.

1.4.2. Les mandats consistent généralement à:

1.4.2.1. Faciliter les affaires de l'Institut.

1.4.2.2. Améliorer l'administration.

1.4.2.3. Améliorer le fonctionnement.

1.4.2.4. Améliorer ou augmenter les activités.

1.4.2.5. Améliorer ou augmenter l'efficacité de l'Institut.

1.5. Comités et conseils spéciaux (ad hoc) 
1.5 Special Committees and Board (ad hoc)

1.5.1. Terms of office will be relative to the tasks involved.

1.5.2. General terms of reference will be to complete assigned tasks

1.6. Working Groups

1.6.1. Working Groups will consist of groups of members interested in a particular field of forestry or related field for the purpose(s) of solving problems and collecting, studying, and disseminating information.

1.6.2. A Working Group may be formed by any ten members on request to and sanctioned by the Executive Committee.

1.6.3. Chairmen of Working Groups may be elected by the Working Group or appointed by the President.

1.6.4. Terms of office may be regulated by the Working Group or the President.

1.6.5. Terms of reference may be set by the Working Group or the President.

1.6.6. Membership in the Working Groups will be by choice of the member. Any Institute member may belong to any two Working Groups.

1.6.7. Activities of the Working Groups will be reviewed by the Executive Committee regularly and the Board of Directors annually.

1.6.8. Working Groups will be self-sufficient but funds may be authorized by the Executive Committee when appropriate. 1.6.9. Every Working Group will submit a written report for the Board of Directors, to the Executive Director seven weeks prior to each Annual Meeting. Working Group chairmen will report to the President on request.

1.6.10. The Executive Director is an ex-officio member of all Working Groups.

1.6.11. Any Working Group may be discharged by the Board of Directors, normally at the end of an Annual Meeting.

\section{Publications General}

2.1. The publications issued by the Institute must be authorized by the Executive Committee. Publications of a policy nature may not be distributed or sold without authorization of the Board of Directors.

2.2. The Forestry Chronicle

The Forestry Chronicle is published by the Institute for the edification and enlightenment of the forestry community. The Editor, who is appointed under contract by the Board of Directors, shall have full authority for the editing and production of the magazine with due consideration to the general wishes of the membership. The Contract with the Editor is for one year, but may be renewed annually and terminated by mutual agreement of the Board of Directors and the Editor. The Editor will report regularly, and when requested, to the Executive Committee and annually to the Board of Directors.

\section{Finances}

\subsection{National Dues}

Active Members 1988-89

1 st and 2 nd year after graduation

(grad of 1988,1987$) \ldots \ldots \ldots \ldots \ldots \ldots \ldots \ldots \$ 70.00$

Other new active members for first year .......\$ 70.00

Married or equivalent,

second members only ...................\$ 70.00

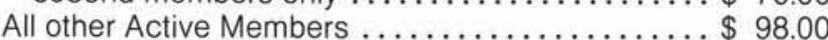

Affiliate Members

1 st and 2 nd year after graduation

(grad of 1988,1987$) \ldots \ldots \ldots \ldots \ldots \ldots \ldots \ldots . \$ 70.00$

Other new affiliate members for first year ...... \$ 70.00
1.5.1. La durée d'exercice varie en relation directe avec les tâches à accomplir.

1.5.2. Les mandats consistent généralement à compléter les tâches assignées.

1.6. Groupes de travail

1.6.1. Les groupes de travail sont formés de membres intéressés à un domaine particulier de la foresterie ou à un domaine connexe dans le but de résoudre certains problèmes et de recueillir, étudier et disséminer l'information.

1.6.2. Un groupe de travail peut être formé de dix membres qui en font la demande et qui obtiennent l'autorisation du Comité exécutif.

1.6.3. Le président d'un groupe de travail peut être élu par les membres du groupe ou nommé par le Président.

1.6.4. La durée d'exercice est établie par le groupe de travail ou par le Président.

1.6.5. Le mandat peut être défini par le groupe de travail ou par le Président.

1.6.6. Tout membre de l'Institut est libre d'adhérer au groupe de travail de son choix. Tout membre peut faire partie de deux groupes de travail.

1.6.7. Les activités des groupes de travail sont passées en revue regulièrement par le Comité exécutif et annuellement par le Conseil d'administration.

1.6.8. Les groupes de travail doivent s'autofinancer mais, Iorsqu'il le juge approprié, le Comité exécutif peut leur attribuer des fonds.

1.6.9. Chaque groupe de travail présente un rapport écrit au Directeur exécutif pour la considération du Conseil d'administration sept semaines avant la tenue de chaque assemblée annuelle. Les présidents des groupes de travai doivent présenter un compte rendu au Président, s'il en fait la demande.

1.6.10. Le directeur exécutif est d'office membre de tous les groupes de travail.

1.6.11. Tout groupe de travail peut être dissous par le Conseil d'administration, normalement à la fin de l'assemblée annuelle.

\section{Publications - Général}

2.1. Les publications de l'Institut doivient être vérifiées et acceptées par le Comité exécutif. Les publications ayant trait aux politiques de l'Institut ne peuvent être distribuées ou vendues sans l'autorisation du Conseil d'administration.

2.2. La revue: The Forestry Chronicle Le Forestry Chronicle est publié par l'Institut pour le bénéfice et l'édification de la communauté forestière. L'éditeur, qui est engagé par contrat par le Conseil d'administration, a pleine autorité concernant l'édition et la production de la revue tout en tenant compte des souhaits généraux des membres. Le contrat avec l'éditeur est d'une durée d'un an, mais il peut être renouvelé annuellement ou abrogé après entente mutuelle entre le Conseil d'administration et l'éditeur. L'éditeur fait rapport régulièrement et sur demande au Comité exécutif et, annuellement, au Conseil d'administration.

\section{Finances}

3.1. Cotisations annuelles au niveau national

Membres actifs 1988-89

1ère et 2ième année suivant l'obtention du diplôme (gradué de 1988,87) ....................\$ 70,00

Autre nouveau membre pour une première année $\$ 70,00$ Conjoint, en tant que deuxième membre ........ \$ 70,00

Tout autre membre actif .................\$98,00 Membres affiliés

1 ère et 2ième année suivant l'obtention du diplôme

(gradué de 1988,87) ..................\$ \$70,00

Autre nouveau membre pour une première année $\$ 70,00$ Conjoint, en tant que deuxième membre ........ \$70,00 
Married or equivalent,

second members only .................\$ 70.00

All other Affiliate Members ..................\$\$ 92.00

Retired and receiving

the Forestry Chronicle ...................\$29.00

Retired and not receiving

the Forestry Chronicle .................\$ 00.00

Student Members ......................... \$ 29.00

Sustaining Members (CIF) ............... \$ 30.00

Sustaining Members (Corporate) ............ \$200.00

3.1.1. New Active and Affiliate and student Members shall be admitted after January 1 st of each year for half dues for that year and after April 1 of each year for zero dues for that year. 3.1.2. Schedule

A dues notice for the ensuing fiscal year will be mailed to each member on or before May 1, of each year.

3.1.3. Any member dropped for non-payment of dues, according to By-law 4.1.3., and wishing to be reinstated may do so on payment of the full current year's dues plus a nil reinstatement fee.

3.2. Section Dues

3.2.1. Section Councils may authorize Head Office to collect Section dues concurrently with national dues.

3.2.2. Section Councils wishing this service or those

already using it and wishing to change Section dues, must notify Head Office by Dec. 1.

3.2.3. Section dues collected by Head Office will be remitted to the Section between August 1 and December 1.

3.3. Annual Meeting

3.3.1. A loan to assist in meeting pre-revenue commitments may be made to Host Annual Meeting Planning Committees on the authorization of the Executive Committee.

3.3.2. Any net surplus resulting from the financing of an Annual General Meeting will be divided so that the first $\$ 1000$ of surplus plus $50 \%$ of the surplus between $\$ 1000$ and $\$ 3000$ plus $10 \%$ of the rest of the surplus will accrue to the Host Section, and the sum remaining to the National Institute.

3.3.3. Any net deficit resulting from the financing of an Annual General Meeting will be divided, with $10 \%$ to be paid by the Host Section and $90 \%$ by the Institute, on the authorization of the Executive Committee.

3.4. Institute Funds

3.4.1. Two signatures are required on all cheques in excess of $\$ 500.00$ drawn on the funds of the Institute.

3.4.2. Signing officers are: all members of the Executive Committee, the Executive Director, members of the Finance Committee, and any other CIF members authorized in writing by the President.

3.4.3. Complete records shall be made for each purchase and a receipt obtained.

3.4.4. The authority to invest funds of the Institute shall be vested, in the Executive Committee, as specified by the Bylaw 5.6., and Rules and Regulations, Sections 3.4.4.

3.4.5. To provide maximum income and high liquidity, the Institute's working capital shall be invested in Short-Term deposits in a chartered bank or trust company.

3.4.6. The Institute's reserve funds will be invested separate from working capital in risk-free bonds or accounts that can be readily converted at par value.

3.4.7. The Executive Committee shall report annually on its actions respecting Institute investments to the Board of Directors.

\subsection{Subscriptions}

Annual subscriptions to The Forestry Chronicle for 1989 will be for non-members will be $\$ C$ dn $\$ 62.00$ in Canada and $\$ C d n 72.00$ in other countries. Subscription for multi-users such as libraries will be \$Cdn 68.00 in Canada and \$Cdn 83.00 in other countries. The price of single copies not more than
Tout autre membre affilié $\ldots \ldots \ldots \ldots \ldots \ldots \ldots \ldots$ \$ 92,00 Membres retraités qui désirent recevoir le Forestry

Chronicle ....................... \$29,00

Membres retraités qui ne désirent pas recevoir le Forestry

Chronicle ........................\$ 00,00

Membres étudiants ..................... \$ 29,00

Membres auxiliaires (membres de l'IFC) ........\$30,00 Membres auxiliaires (société) .............. \$200,00 3.1.1. Tout nouveau membre actif, affilié ou étudiant admis après le 1er janvier de chaque année paye une demicotisation pour cette année et après le 1er avril de chaque année paye zero cotisation pour cette année.

3.1.2. Un avis de cotisation pour l'année fiscale suivante est posté à chaque membre au plus tard le 1er mai de chaque année.

3.1.3. Toute adhésion annulée faute de paiement de la cotisation, tel que prévu aux règlements (4.1.3.), peut être renouvelée sur paiement de la cotisation d'une année complète plus un droit de réinscription de zero.

3.2. Cotisation de Section

3.2.1. Les Conseils de Section peuvent autoriser le siège social à percevoir les cotisations de section en même temps que la cotisation nationale.

3.2.2. Les Conseils de Section qui désirent profiter de ce service, ou ceux qui en profitent déjà et qui veulent changer la cotisation de Section, doivent en aviser le siège social avant le 1 er décembre.

3.2.3. Les cotisations de Section perçues par le siège social sont remises aux Sections entre le 1er août et le 1er décembre.

3.3. Assemblée annuelle

3.3.1. Le Comité exécutif peut autoriser un prêt pour aider le comité HAMPCO à rencontrer ses engagements financiers avant l'assemblée annuelle.

3.3.2. Tout surplus provenant des opérations financières d'une assemblée générale annuelle est réparti de façon à ce que le premier $\$ 1000$ et $50 \%$ du montant entre $\$ 1000$ et $\$ 3000$ et $10 \%$ du montant excédant $\$ 3000$ soit versé à la Section hôte de l'assemblée et le reste à l'Institut.

3.3.3. Tout déficit provenant des opérations financières d'une assemblée générale annuelle est divisé de façon à ce que $10 \%$ soit assumé par la Section hôte et $90 \%$ par l'Institut, sur autorisation du Comité exécutif.

3.4. Les fonds de l'Institut

3.4.1. Deux signatures sont nécessaires sur tous les chèques émis par l'Institut de plus de $\$ 500.00$.

3.4.2. Les officiers qui peuvent signer sont tous les membres du Comité exécutif, le directeur exécutif, les membres du Comité des finances, et tout autre membre de l'IFC détenteur d'une autorisation écrite du Président.

3.4.3. Le directeur exécutif tient un record complet de tous les achats effectués et de tous les reçus émis en faveur de I'Institut.

3.4.4. La responsabilité d'investir les fonds de l'Institut est dévolue au Comité exécutif tel qu'indiqué aux règlements (5.6) et aux règles de pratique, section 3.4.4.

3.4.5. Pour s'assurer un revenu maximum et une grande liquidité, le fonds de roulement de l'Institut est investi dans un dépôt à court terme, dans une banque à charte ou un trust. 3.4.6. Le fonds de réserve de l'Institut est investi séparément du fonds de roulement, soit dans des certificats de placement sans risque qui peuvent être encaissés en tout temps à leur valeur au pair, soit dans un ou des comptes de banque.

3.4.7. Le Comité exécutif présente au Conseil d'administration un rapport annuel concernant les investissements de l'Institut.

3.5. Abonnements

Le tarif annuel pour la revue The Forestry Chronicle en 1989 
two years old shall be $\$ 7.50$ postpaid in Canada and $\$ C$ dn 10.00 to other Countries.

The price of single copies more than two years old shall be \$Cdn 10.00 postpaid to any destination.

\section{Miscellaneous}

4.1. Honorary and Fellow Membership

Proposals for Honorary and Fellow Membership must be received by the Executive Director by May 1 in order to be considered by the Board of Directors at their next Annual Meeting.

\subsection{Resolutions}

Resolutions for consideration at an Annual General Meeting, excepting those arising from the business of that meeting and those expressing appreciation, shall be submitted to Head Office by five weeks in advance of the Annual General Meeting, then forwarded to the Chairman of the Resolutions Committee for study, revision, or approval or rejection as the Committee may deem necessary. The Chairman ot the Resolutions Committee shall submit approved resolutions fo the Executive Director by the first of August. The Executive Director shall then, without delay, submit approved resolutions to all Directors.

4.3. Awards

4.3.1. Canadian Forestry Achievement Award

Each year nominations submitted on or before May 1 are to be considered by the Executive Committee for the Canadian Forestry Achievement Award. The award to be presented annually or from time to time shall consist of an appropriate award, a certificate, and a citation.

4.3.2. Canadian Forestry Scientific Achievement Award Each year nominations submitted on or before May 1 are to be considered by the Executive Committee for the Canadian Forestry Achievement Award. The award, to be presented annually or from time to time, shall consist of an appropriate award, a certificate, and a citation.

4.3.3. Canadian Institute of Forestry Medals

Medals, one for each professional forestry school in Canada, shall be given annually or from time to time to graduating students who shall be selected by the head of the school and for outstanding scholarship, sports and citizenship recorded throughout all years of the course.

4.3.4. Schlich Memorial Prize

An award known as the Schlich Memorial Prize and consisting of the accumulation of interest on the Schlich Memorial Fund held in trust by the Institute, shall be given annually or from time to time (and in rotation to each professional forestry school in Canada) to a deserving forestry student as selected by the head of his school.

4.3.5. Foresters' Rings

Foresters' Rings shall be given annually to the forestry baccalaureate graduates of that year of the Canadian Universities.

4.4. Privileges of Sustaining Members

All Sustaining Members shall be listed annually in the Forestry Chronicle and shall receive a special membership card. Sustaining Membership shall in no other way restrict or enhance the rights and responsibilities relating to any other class of membership. Sustaining Members who are not otherwise members of the Institute may enjoy such other benefits and privileges as are approved by resolution of the Institute.

The By-laws are published in English and French. In the case of difficulty in interpretation, the English version is regarded as authorative. pour les non-membres sera de $\$ c d n 62.00$ au Canada et de $\$ c d n 72.00$ ailleurs. Le tarif pour les bibliothèques et institutions semblables sera de $\$ c d n 68.00$ au Canada et $\$ c d n$ 83.00 ailleurs. Le prix par copie datant de moins de deux ans est de \$cdn 7.50 port payé au Canada et de \$cdn 15.00 ailleurs. Le prix par copie datant de plus de deux ans est de $\$ 10.00$ port payé toute destination.

\section{Divers}

\subsection{Membres honoraires et émérites}

Les propositions de nomination à titre de membre honoraire et émérite doivent parvenir au bureau du directeur exécutif avant le 1er mai pour que le Conseil d'administration puisse les considérer lors de l'assemblée annuelle suivante.

4.2. Résolutions

Les résolutions soumises pour étude lors de l'assemblée générale annuelle, à l'exception de celles qui ont une relation directe avec le sujet de l'assemblée et les résolutions dites d'appréciation, doivent parvenir au siège social cinq semaines avant l'assemblée générale annuelle. Elles sont ensuite acheminées au président du comité des résolutions pour étude, révision, approbation ou refus. Le président de ce comité soumet les résolutions approuvées au directeur exécutif avant le 1er août. Ce dernier doit alors, sans délai, soumettre ces résolutions à tous les membres du Conseil d'administration.

4.3. Prix

4.3.1. Prix décerné pour une réalisation exceptionnelle dans le domaine de la foresterie au Canada. Chaque année, les mises en candidature pour ce prix sont soumises au Comité exécutif pour examen avant le 1er mai. Le prix décerné annuellement ou lorsque nécessaire consiste en une récompense appropriée, un certificat et une mention.

4.3.2. Prix décerné pour une réalisation scientifique exceptionnelle dans le domaine de la foresterie au Canada Chaque année les candidatures pour ce prix sont soumises au Comité exécutif pour examen avant le 1er mai. Le prix, qui est présenté annuellement ou de temps à autre, consiste en une récompense appropriée, un certificat et une mention.

4.3.3. Médailles de I'Institut forestier du Canada

Une médaille est décernée annuellement ou de temps à autre dans chacune des facultés de foresterie du Canada à un finissant choisi par le doyen et reconnu pour son dynamisme exceptionnel tout au long de son cours dans les domaines scolaire, sportif et civique.

4.3.4. Prix commémoratif Schlich

Une prix en argent équivalent à l'intérêt accumulé dans le fonds commémoratif Schlich, détenu en fiducie par l'Institut et connu sous le nom de Prix commémoratif Schlich, est attribué annuellement ou de temps à autre (en alternant d'une faculté de foresterie à une autre au Canada) à un étudiant méritant choisi par le doyen.

4.3.5. Joncs d'ingénieurs forestiers

Les joncs d'ingénieurs forestiers sont donnés chaque année à tous les gradués des facultés de foresterie du Canada.

4.4. Privilèges des membres auxiliaires

La liste de tous les membres auxiliaires est publiée chaque année dans le Forestry Chronicle. Ils reçoivent une carte spéciale de membre. La classe de membre auxiliaire ne doit en aucune façon restreindre ou rehausser les droits et responsabilités de toute autre classe de membre. Les membres auxiliaires qui ne sont pas autrement membres de l'Institut peuvent jouir de tout autre bénéfice et privilège approuvé par résolution de l'Institut.

4.5. Les règles de pratique sont rédigées en anglais et en français. En cas de difficulté d'interprétation, la version anglaise est officielle.

Texte traduit de l'anglais par G. Paillé; revu par Claude Turmel, François Matte et François Sauvageau. 